\title{
PENGEMBANGAN PEMASARAN ONLINE UNTUK PELAKU USAHA DI DESA WARNASARI, KECAMATAN PANGALENGAN, KABUPATEN BANDUNG
}

\author{
Yulia Segarwati ${ }^{1}$, Charisma Asri Fitrananda ${ }^{2}$, \\ Mochamad Iqbal3, Vikry Abdullah Rahiem4 \\ Jurusan Ilmu Komunikasi, FISIP Universitas Pasundan \\ Email: 1yulia.segarwati@unpas.ac.id,2charisma.asri@unpas.ac.id, \\ 3moch.iqbal@unpas.ac.id, 4vikry.ar@gmail.com.
}

\begin{abstract}
Abstrak
Pengabdian ini bertujuan untuk memberikan sosialisasi pemanfaatan media online sebagai sarana pemasaran hasil produksi anggota Karang Taruna Desa Warnasari, Kecamatan Pangalengan, Kabupaten Bandung dengan harapan dapat memperluas area pemasaran yang akan memberikan imbas terhadap peningkatan omset. Adapun masalah yang dimiliki oleh mitra adalah kurangnya kemampuan serta pengelolaan manajemen usaha mitra masih terbatas, terutama dalam memperkenalkan produk unggulannya ke khalayak sasaran pasar mereka yang lebih luas lagi melalui kegiatan promosi yang tepat sasaran baik secara offline maupun online Kegiatan ini menggunakan metode pendekatan kontektual yaitu memberikan materi teori terlebih dahulu dan dilanjutkan dengan workshop langsung mengunggah produk-produk yang dihasilkan oleh anggota Karang Taruna yang merupakan pelaku usaha. Lalu dilanjutkan dengan metode pengarahan teknik pemasaran online dan pendampingan usaha. Metode ini langsung dipraktikkan oleh instruktur dengan mitra agar mitra dapat langsung memahami aplikasi-aplikasi marketplace dan pendampingan dalam pengembangan pengetahuan dan kemampuan untuk mengakses marketplace secara online, serta memfasilitasi kegiatan promosi melalui media online (e-commerce dan social media). Hasil pelatihan menunjukkan bahwa peserta pengabdian sangat tertarik mengikuti pelatihan- pelatihan semacam ini karena sangat merasa terbantu dalam memanfaatkan media online sebagai sarana pemasaran hasil produksi yang sudah berkembang pesat dewasa ini. Adanya optimalisasi kinerja melalui peningkatan daya kreativitas dan inovasi SDM, yaitu melalui pemahaman konsep startegi pemasaran, terutama melalui kemampuan pemasaran online, sehingga mitra mampu memperkenalkan produk usaha lebih luas lagi dan menciptakan sebuah destination branding melalui media online.
\end{abstract}

Kata kunci: karang taruna, online, pemasaran

\begin{abstract}
This service aims to provide online socialization media as a marketing tool for the production of members of the Youth Association of Warnasari Village, Pangalengan District, Bandung Regency in the hope that it can expand the marketing area which will have an impact on increasing turnover. Related to the problems offered by partners is the additional requirements and management of partner management is still limited, priority in supporting superior products to their wider target market audience through promotional activities that are
\end{abstract}


targeted both offline and online This activity uses a controversial method, which is to provide material first and then proceed with workshops that directly upload products produced by members of the Karang Taruna who are the ones who strive. Then proceed with the method of directing online marketing techniques and business assistance. This method is directly practiced by instructors and partners to be able to directly access marketplace applications and assistance in developing knowledge and capabilities to access the marketplace online, as well as facilitating promotional activities through online media (e-commerce and social media).The results of the training showed that the service participants were very interested in participating in such trainings because they were greatly helped in utilizing online media as a means of marketing the products that had been rapidly exported. The optimization of performance through increasing the power of creativity and innovation of $H R$, namely through understanding marketing strategy concepts, specifically through online marketing capabilities, so that partners can provide business products more broadly and create branding goals through online media.

Keywords: marketing, online 


\section{PENDAHULUAN}

Salah satu sektor yang penting dan besar kontribusinya dalam mewujudkan sasaran pembangunan ekonomi nasional adalah Karang Taruna. Adapun sasarannya adalah seperti pertumbuhan ekonomi, kesempatan kerja, peningkatan devisa dan pembangunan ekonomi daerah, diharapkan Karang Taruna mempunyai kemampuan untuk ikut memacu pertumbuhan ekonomi nasional. Perkembangan sektor usaha kecil menengah yang dikelola oleh Karang Taruna khususnya di Desa Warnasari merupakan bagian dari Kecamatan Pangalengan Kabupaten Bandung Provinsi Jawa Barat. Desa Warnasari memiliki luas wilayah 2.354,119 Hektar, terletak pada ketinggian $\pm 1442 \mathrm{mdpl}$ dan memiliki suhu udara rata-rata $12^{\circ} \mathrm{C}-25^{\circ} \mathrm{C}$. Batas wilayah Desa Warnasari adalah sebelah utara Desa Pulosari, sebelah timur Desa Pulosari, sebelah selatan Desa Margaluyu dan sebelah barat Desa Pasir Jambu.

Desa Warnasari memiliki 17 Rukun Warga dan 17 kampung yaitu Baru Taraje, Ciawitali, Cibeunying, Cibunihayu, Cidurian, Cipangisikan, Citiis, Kapas, Kiaracondong, Munjul, Neglasari, Padahurip, Palayangan, Parabon, Pasir Ucing, Singkur, dan Wanasari. Lokasi TPK Warnasari berada didepan Jalan utama Desa Warnasari di RW 02 Kampung Wanasari berjarak \pm 300 meter ke sebelah barat dari kantor Desa Warnasari. Penempatan TPK Warnasari yang terletak di lokasi pusat desa mudah dijangkau oleh para peternak di daerah utara dan selatan serta memudahkan truk untuk mendistribusikan susu yang dikumpulkan peternak ke lokasi industri pengolahan susu.

Berdasarkan gambaran di atas, Desa Warnasari mempunyai potensi yang besar sebagai daerah penghasil produk pertanian yang dapat dikembangkan sebagai agroindustri dan agrowisata. Selain padi dan palawija, yang merupakan hasil pertanian secara umum, Desa Warnasari juga dikenal sebagai penghasil beberapa produk pertanian holtikultura. Dalam upaya pengembangan usaha tani di Desa Warnasari, pada dasarnya diperlukan keterlibatan para pelaku yang terdiri dari berbagai pihak seperti penghasil produk, pengolah, pedagang, distributor, importir dan eksportir. Pelaku-pelaku ini (C) Yulia Segarwati, Charisma AF, M. Iqbal, Vikry AR. merupakan komponen atau subsistem yang membentuk sebuah sistem agribisnis. Sistem tersebut, di tahun-tahun mendatang diharapkan agar lebih berfungsi secara optimal demi mewujudkan tingkat kesejahteraan masyarakat. Oleh karena itu, pemerintah Desa Warnasari melalui program pembinaan dan pemberdayaan masyarakat akan selalu berupaya agar semua subsistem itu lebih siap dalam menjalankan perannya secara profesional.

Karang Taruna mengembangkan beberapa macam usaha di Desa Warnasari mempunyai target pasar kalangan menengah ke bawah. Tetapi karena berkembangnya permintaan dari konsumen yang mulai beragam seiring dengan berkembangnyasektor pariwisata, maka target pasar ingin berubah menjadi kalangan menengah ke atas. Adapun usaha yang dilakukan oleh Karang Taruna di Desa Warnasari adalah pengusaha kopi, keripik kentang, tomat, sayuran dan wisata. Aspek strategi pemasaran mitra tidak jauh berbeda yaitu dilakukan secara offline dengan pendistribusian ke toko dan mengikuti pameran. Promosi melalui media online, instagram, facebook, twitter tetapi tidak efektif dan menjadi sponsorship di berbagai acara.

Desa Warnasari yang tidak seluruh wilayahnya dapat dikembangkan untuk pertanian, serta keragaman komoditas di tingkat petani dan kebijakan pemerintah yang tidak sama, telah menyebabkan perbedaan persepsi tentang komoditas yang tepat untuk dikembangkan di Warnasari. Maka untuk mengkaji komoditas unggulan. Desa Warnasari yang sesuai dengan agroklimat dalam pengembangan usaha tani holtikultura, perlu dilakukan serangkaian penelitian yang intensif.

Desa Warnasari sebenarnya berada pada daerah yang strategis yang berdekatan dengan potensi wisata Situ Cileunca. Hawa pegunungan dan keindahan alam yang dimiliki Warnasari, turut mendukung bagi pengembangan sektor pariwisata. Hal ini dapat menjadikan daerah Warnasari Pangalengan sebagai kawasan pariwisata. Namun selama ini masyarakat maupun pemerintah Desa seolah hanya sebagai "penonton" dalam pengelolaan wisata Situ Cileunca. Dari kegiatan penelitian itu, 
Pemerintah Desa berharap memiliki referensi untuk menentukan arah kebijakan yang berkaitan dengan sektor pertanian dan perkebunan. Kegiatan usaha yang dilakukan oleh Karang Taruna berjalan sejak tahun 2004 dan telah mengalami perkembangan yang positif. Namun dengan permasalahan yang dihadapi, seperti mitra mempunyai masalah sebagai berikut:

a. Mitra mengalami penurunan produktivitas karena terbatasnya kapasitas produksi, terutama keterbatasan bahan baku, penggunaan alat produksi yang masih sederhana dan keterbatasan tenaga kerja.

b. Mitra belum mampu memunculkan ciri khas produk dari usaha yang diproduksinya, terutama di bagian kemasannya.

c. Pengetahuan, kemampuan serta pengelolaan manajemen usaha mitra masih terbatas, terutama dalam memperkenalkan produk unggulannya ke khalayak sasaran pasar mereka yang lebih luas lagi melalui kegiatan promosi yang tepat sasaran baik secara offline maupun online.

d. Khususnya, mitra belum memiliki pengetahuan dan kemampuan yang cukup dalam mengakses marketplace untuk memasarkan usahanya secara online.

Berdasarkan permasalahan yang telah teridentifikasi pada mitra, maka untuk menentukan kesepakatan dalam pemecahan masalah prioritas yang segera dicarikan solusinya, dengan tujuan peningkatan produksi dan penjualan usaha seperti pendampingan dalam pengembangan pengetahuan dan kemampuan untuk mengakses marketplace secara online dan memfasilitasi kegiatan promosi melalui media online (e-commerce dan social media). Berdasarkan kegiatan usaha dan permasalahan yang dihadapi oleh mitra, maka tim pengabdian mengambil rujukan dari artikel Marketing Communication Strategy Small and Medium Enterprises (SMEs) "Marcin" Herbal Shop in Bandung (C) Yulia Segarwati, Charisma AF, M. Iqbal, Vikry AR. yang ditulis oleh Dhini Ardhianti dalam meningkatkan produksi dan penjualan usaha, sehingga mampu memenuhi permintaan pasar secara berkesinambungan dan memiliki pangsa pasar yang luas sebagai produk yang diminati masyarakat dengan konsep unik dan khas.

Adapun tahapan yang dapat diambil diaplikasikan dengan masalah mitra di Desa Wanasari adalah:

1. Mitra mampu menunjukkan ciri khas (branding) melalui peningkatan kualifikasi keahlian tenaga kerja (SDM) di bidang promosi.

2. Mitra mampu memperkenalkan produk usaha secara lebih luas lagi melalui kegiatan promosi di media online $e$ commerce dan social media.

3. Mitra mampu meningkatkan penjualan produk.

\section{METODE PELAKSANAAN}

Metode kegiatan yang dipakai oleh tim ada tiga tahap yaitu metode pendekatan, metode pengarahan dan metode pendampingan.

\section{a. Metode Pendekatan}

Metode pendekatan yang digunakan untuk luaran pengabdian kepada masyarakat di Desa Warnasari, diterapkan untuk mengetahu khalayak sasaran Pengabdian Kepada Masyarakat agar ilmu yang diimplementasikan dapat tepat guna sampai kepada Mitra. Dalam hal ini tim pengabdian melakukan observasi terlebih dahulu ke Desa Wanasari untuk melihat masalah apa saja yang dialami oleh mitra. Sehingga didapatkan bahwa permasalahan yang dimiliki adalah teknik marketing pariwisata yang masih kurang dieksplorasi, sehingga banyak informasi yang tidak tersampaikan kepada calon wisatawan.

\section{b. Metode Pengarahan}

Pengarahan teknik pemasaran yaitu dalam bentuk pelatihan media promosi online melalui marketplace maupun media-media sosial lainnya (instagram, twitter, fanpage Facebook). Pengarahan ini ditujukan kepada mitra untuk memahami peran, fungsi, tujuan media promosi online, memahami langkahlangkah dalam mengaktifkan sebuah $e$ 48 | Ka i b o n A b h in a y a 
commerce, seperti: membuat akun, menentukan isi konten, strategi memiliki follower sebanyak-banyak melalui instagram, twitter, fanpage facebook; dan lain- lain.

c. Metode Pendampingan Usaha

Metode pendampingan dilakukan sehingga dapatmengimplementasikan pengelolaan usahanya lebih baik lagi, guna mencapai tujuan usaha yang diharapkan dan memberikan solusi atas permasalahan yang dihadapi. Metode ini langsung dipraktikkan oleh instruktur dengan mitra agar mitra dapat langsung memahami aplikasi marketplace dan bisa berdiskusi jika ada yang belum dimengerti.

Adapun jenis luaran dalam Program Kemitraan Masyarakat pada Usaha Karang Taruna di Desa Warnasari, adalah sebagai berikut:

a. Mitra mampu memperbaiki branding/image produk dengan menunjukkan ciri khas produk melalui desain produk kemasan yang mereka ciptakan.

b. Peningkatan

kegiatan pemasaran/promosi, sehingga produk usaha mitra dapat dikenal lebih luas di masyarakat dengan pemasaran yang lebih luas lagi melalui media online.

c. Kedua mitra mampu membuka lapangan kerja bagi masyarakat sekitar lokasi mitra untuk memenuhi kebutuhan tenaga kerja mitra serta mampu mengelola dan meningkatkan kualifikasi sumber daya manusia bagi kedua mitra.

\section{HASIL DAN PEMBAHASAN}

Kegiatan Pengabdian Kepada Masyarakat telah dilaksanakan di lokasi Desa Warnasari, Kecamatan Pangalengan, Kabupaten Bandung berlangsung sesuai dengan jadwal yaitu 3 minggu mulai dari tahap persiapan, pelaksanaan dan pelaporan. Pada tahap persiapan, tim telah menentukan waktu kegiatan akan mulai dilaksanakan, pada tahap awal tim berkoordinasi dengan mitra untuk segera melaksanakan kegiatan sesuai dengan jadwal kegiatan. Dalam pelaksanaan program di lapangan kedua Mitra ikut berpartisipasi dalam menentukan waktu, dan tempat pelaksanaan. Untuk lebih jelasnya, tahap pelaksanaan kegiatan PKM di Desa Warnasari, Kecamatan Pangalengan, Kabupaten Bandung seperti melakukan kunjungan awal ke tempat mitra, melakukan analisis dengan proses wawancara untuk mengetahui apa kendala dihadapi oleh mitra, menyusun rencana pengabdian, melakukan pelatihan dan evaluasi. Tim melakukan kunjungan ke tempat produksi mitra (kantor manajemen dan pabrik/workshop) yang bertempat di Desa Warnasari, Kecamatan Pangalengan, Kabupaten Bandung. Dalam beberapa kunjungan, tim melihat tempat pelaku usaha yang mayoritas dipegang oleh Karang Taruna yang digunakan untuk produksi usaha seperti kopi, keripik, tomat, sayuran dan wisata. Tim melihat alur proses produksi, pemakaian dan pengolahan bahan baku, pengemasan dan kelengkapan proses produksi lainnya.

Selain itu melihat bagaimana pengelolaan manajemen usaha yang dilakukan terkait $\mathrm{SDM} /$ pegawai yang bekerja dalam produksi. Dalam sehari bagian produksi menghabiskan waktu 8 jam. Pegawai yang membantu mitra sebagian besar adalah warga Desa Warnasari dan sekitarnya. Namun, pegawai di bidang produksi ini kualifikasi pendidikannya pun belum memiliki pengalaman dalam melakukan strategi di bidang pemasaran offline maupun online. Oleh sebab itu, khusus bidang pemasaran/promosi, mitra masih memanfaatkan jaringan pertemanan yang mereka miliki atau bahkan anggota keluarga yang cukup melek teknologi dan memiliki keinginan untuk mempelajari hal-hal yang baru. Dalam kesempatan inilah, tim mengajak mitra untuk dapat mengikuti pelatihan pemasaran online yang difasilitasi dalam kegiatan PKM ini. Untuk meningkatkan produktifitas dan manajemen usaha salah satunya adalah melalui peningkatan kualifikasi sumber daya manusia. Dilihat dari segi permasalahan yang ada pada mitra, yaitu dalam bidang pemasaran dan promosi online untuk memberi nilai tambah (ciri khas) atau keunikan produk sehingga dapat lebih dikenal oleh masyarakat luas (branding). Maka diperlukan kegiatan pelatihan/workshop sebagai solusi terhadap permasalahan tersebut. Pelatihan pemasaran online dilakukan untuk memberikan pemahaman kepada mitra bahwa perlu adanya teknik pemasaran melalui media online karena masalah pemasaran ini merupakan masalah yang paling krusial yang dihadapi oleh mitra, karena keterbatasan alat elektronik dan pemahaman dunia digital. Sejauh ini kedua mitra belum 
mempunyai akun media sosial dan ecommerce dalam pemasarannya, hanya melakukan pemasaran konvensional seperti pameran/event, personal selling dan display.

Sedangkan pasar sudah berubah, target pasar tidak hanya konvensional saja, tetapi banyak target pasar di era digital. Pelatihan pemasaran online diberikan secara teori dan praktek dalam dua pertemuan yang berbeda. Untuk pelatihan secara teori, mitra diberikan materi pemahaman tentang strategi komunikasi pemasaran di era digital, kemudian mengenai akun media sosial, e- commerce, website, SEO dan target pasar digital. Sedangkan untuk praktek, kedua mitra dibuatkan akun media sosial dan ecommerce serta bagaimana cara mengaplikasikannya secara langsung oleh instruktur. Sebagai narasumber dalam pelatihan ini selain Tim Pelaksana adalah seorang akademisi Prodi Ilmu Komunikasi Unpas dan pakar Digital Marketing.

Pelatihan ini dilakukan pada Sabtu, 26 Februari 2019 bertempat di Gedung Serbaguna Desa Warnasari, Kecamatan Pangalengan, Kabupaten Bandung. Acara dimulai pukul hingga pukul 16.00 WIB, dihadiri oleh 25 orang peserta. Selama kegiatan berlangsung diliput oleh media massa cetak maupun online. Berdasarkan permasalahan yang dipaparkan sebelumnya, melalui kegiatan PKM ini luaran yang dihasilkan adalah sebagai berikut: adanya peningkatan kualifikasi SDM (Sumber Daya Manusia) dalam bidang pemasaran dan promosi online. Pihak manajemen usaha memahami pentingnya kegiatan pemasaran dan promosi online, juga memahami bagaimana strategi komunikasi pemasaran yang harus dilakukan oleh usaha mereka. Selain itu, pihak manajemen mampu mempraktekan kegiatan pemasaran online dengan cara membuat account di salah satu media sosial, seperti Instagram dan berjualan di tokopedia.

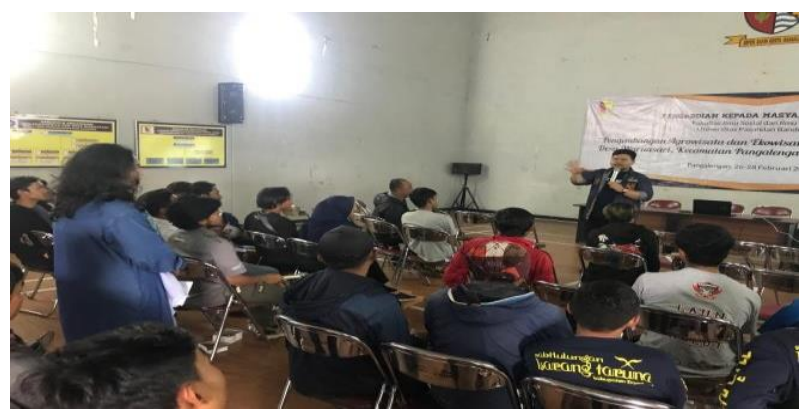

Gambar 1. Materi marketplace oleh Vikry A. $\mathrm{R}$

Materi yang diberikan oleh narasumber yaitu Vikry A. R adalah mengenai transaksi perdagangan online (ecommerce) di Indonesia yang memiliki masa depan cerah. Pasalnya, nilai transaksinya terus meningkat selama lima tahun terakhir. Marketplace adalah salah satu pemain terbesar dalam bisnis ecommerce Indonesia. Berdasarkan data yang dirilis Katadata, pada tahun 2014 nilai transaksi perdagangan online Indonesia hanya berada di angka 25,1 triliun rupiah dan pada tahun 2016 sudah mencapai angka 108,4 triliun rupiah. Diperkirakan pada tahun 2018 nilai transaksi tersebut akan meningkat hingga 144,1 triliun rupiah.

Aktivitas jual beli secara online memang sedang naik daun dalam beberapa tahun belakangan. Berjualan online dapat dilakukan melalui online shop atau marketplace. Apa saja perbedaan di antara keduanya? Apa itu marketplace? Bagaimana pengertian marketplace dan online shop?

Jumlah situs marketplace di Indonesia mengalami peningkatan dalam beberapa tahun belakangan. Beberapa situs marketplace yang paling populer di Indonesia adalah Bukalapak, Shopee, Tokopedia, OLX, Zalora,Blibli, dan Lazada. Situs-situs marketplace adalah perantara antara penjual dan pembeli di dunia maya. Situs marketplace bertindak sebagai pihak ketiga dalam transaksi online dengan menyediakan tempat berjualan dan fasilitas pembayaran. Pada umumnya terdapat dua jenis kerja sama di situs marketplace Indonesia, yaitu marketplace murni dan konsinyasi.

\section{Marketplace Murni}

Kerjasama marketplace murni adalah ketika situs marketplace hanya menyediakan 
lapak untuk berjualan dan fasilitas pembayaran. Penjual yang melakukan kerjasama marketplace diberikan keleluasaan lebih banyak dibandingkan kerjasama konsinyasi. Penjual berkewajiban untuk menyediakan deskripsi dan foto produk secara mandiri. Selain itu, penjual juga dapat menerima penawaran harga dari pembeli. Jadi sebelum melakukan pembayaran, pembeli dapat melakukan penawaran harga kepada penjual. Setelah mendapatkan harga yang disepakati oleh kedua belah pihak, pembeli bisa mengirimkan sejumlah uang ke rekening yang disediakan marketplace.

\section{Marketplace Konsinyasi}

Jenis kerjasama yang kedua adalah konsinyasi atau istilah mudahnya adalah titip barang. Jika penjual melakukan kerjasama konsinyasi dengan situs ecommerce, ia hanya perlu menyediakan produk dan detail informasi ke pihak ecommerce. Salah satu contoh marketplace yang menyediakan kerjasama konsinyasi adalah Zalora. Contoh marketplace lain yang menggunakan jenis kerjasama ini adalah Berrybenka. Pihak situs ecommerce akan mengurus penjualan dari foto produk, gudang, pengiriman barang, hingga fasilitas pembayaran. Berbeda dari jenis kerjasama sebelumnya, di jenis kerjasama ini pembeli tidak bisa melakukan penawaran harga karena alur semua alur transaksi ditangani oleh situs ecommerce. Perbedaan mendasarnya terletak pada tanggung jawab penjual dan alur transaksinya. Alur transaksi di marketplace terjadi langsung antara penjual dan pembeli, sedangkan kerjasama konsinyasi semua alur transaksi langsung ditangani situs ecommerce. Dua cara berjualan online di atas memiliki kelebihan

kekurangannya masing-masing. Secara keseluruhan membuat website toko online sendiri mempunyai keuntungan lebih banyak dibandingkan hanya mengandalkan marketplace saja. Membuat website toko online adalah prioritas utama bagi para penjual online, terutama yang sudah memiliki merek sendiri. Selain bisa menjadi sarana promosi, website toko online juga meningkatkan kepercayaan pelanggan terhadap merek sendiri.

Selain memberikan materi mengenai pemasaran online, narasumber Mochamad Iqbal memberikan materi mengenai destination branding untuk mendukung pengembangan daerah. Narasumber melakukan metode pendampingan agar mitra sapat langsung mengaplikasikan materi yang diberikan oleh narasumber. Pendampingan dilakukan dengan pembuatan konten video mengenai keunggulan daerahnya dan akan dipublikasikan secara online melalui media sosial instagram. Hal ini dilakukan untuk mendukung pengembangan daerah Desa Warnasari, Kecamatan Kabupaten Bandung dari sisi pariwisata.

Saat ini pariwisata menjadi salah satu tren yang berkembang cukup pesat dan dianggap sebagai industri yang cukup menjanjikan, alasannya karena pariwisata memiliki banyak manfaat bagi masyarakat juga negara baik dari segi ekonomi, budaya, lingkungan, ilmu pengetahuan, dan lainnya. Maka dari itu, narasumber memberikan materi mengenai bagaimana membuat konten video pariwisata yang menarik.

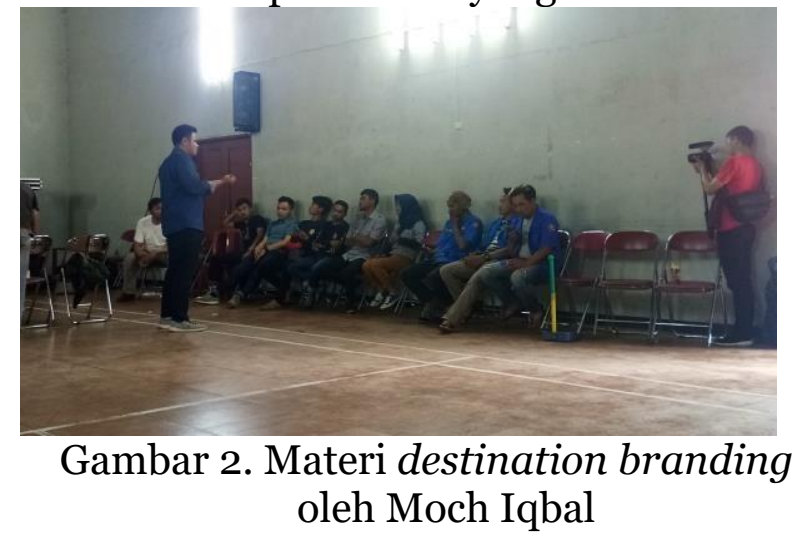

Dengan banyaknya manfaat yang dihasilkan oleh sektor pariwisata, pemerintah telah memutuskan untuk menjadikan pariwisata sebagai lini sektor utama. Oleh sebab itu, diperlukan usahausaha untuk memasarkan suatu destinasi wisata agar lebih dikenal oleh wisatawan baik nusantara maupun mancanegara. Selain itu, usaha-usaha memasarkan destinasi juga berguna agar destinasi wisata tersebut memiliki masa hidup yang lebih panjang.

Terdapat beberapa aspek dan tahapan yang perlu dipertimbangkan untuk melakukan pemasaran. Bila pernah mendengar tentang Positioning- 
Differentiation-Branding menurut Hermawan Kartajaya, tiga dasar itulah yang digunakan dalam sebuah pemasaran, termasuk dalam pemasaran destinasi pariwisata. Setelah mengetahui Positioning suatu destinasi (bagaimana suatu destinasi ingin dikenal atau diingat oleh konsumen), kemudian mengetahui Differentiation (pembeda suatu destinasi dari destinasi pesaing lainnya), yang perlu dilakukan selanjutnya adalah Branding. Jika membicarakan branding secara lengkap, tentunya diperlukan satu buku tebal khusus untuk membahas topik tersebut. Secara garis besar, Brand merupakan sebuah janji perusahaan atau pengalaman konsumen yang terasosiasi dengan suatu produk. Membangun brand tidak bisa terjadi dalam satu malam, membangun brand adalah sebuah proses yang panjang dan cukup sulit untuk dilakukan. Tapi kesuksesan dalam membangun brand ini bisa menghasilkan hubungan jangka panjang.

Brand dalam suatu destinasi wisata sangat diperlukan untuk menghadapi persaingan. Salah satu persaingan yang terjadi antar destinasi adalah tidak dikenalnya suatu destinasi dibandingkan dengan destinasi lain, padahal kedua destinasi tersebut menawarkan produk yang serupa, atau berbeda namun dengan keunikan masingmasing. Brand Destinasi dapat mempermudah wisatawan untuk membedakan suatu destinasi dengan destinasi lainnya.

\section{Kesimpulan dan Saran}

Berdasarkan kegiatan yang telah dilakukan tim Pengabdian Kepada Masyarakat di Desa Warnasari, Kecamatan Pangalengan, Kabupaten Bandung dapat diambil kesimpulan bahwa pelaksanaan peningkatan kualifikasi SDM berupa pelatihan pemasaran online di bidang pariwisata dengan melakukan pendampingan pembuatan akun media sosial dan $e$ commerce

Adanya optimalisasi kinerja melalui peningkatan daya kreativitas dan inovasi SDM, yaitu melalui pemahaman konsep startegi pemasaran, terutama melalui kemampuan pemasaran online, sehingga mitra mampu memperkenalkan produk usaha lebih luas lagi dan menciptakan sebuah destination branding melalui media online. Dari pelaksanaan kegiatan PKM ini ada beberapa saran yang dapat dijadikan masukan untuk mitra, yaitu mitra disarankan untuk selalu berinovasi dan meningkatkan kualifikasi SDM yang dapat mengikuti trend perkembangan terkini (up to date).

Pemasaran yang dilakukan mitra harus senantiasa mengikuti perkembangan zaman yaitu mempunyai kemampuan di bidang media online dan digital, agar tidak kalah bersaing dengan perusahaan lainnya. Pemerintah diharapkan dapat lebih memperhatikan usaha-usaha kecil yang memiliki potensi kedaerahan dan menjunjung kearifan lokal, sebagaimana pelaku usaha yang diprakarsai oleh Karang Taruna, sehingga turut mengangkat potensi pariwisata daerah.

\section{DAFTAR REFERENSI}

Kertamukti, Rama. 2015. Strategi Dalam Periklanan. Jakarta: PT. Raja Grafindo Persada. Kotler, Philip; Armstrong, Garry, 2008. Prinsipprinsip Pemasaran, Jilid 1, Erlangga, Jakarta.

Bungin, Burhan. 2015. Komunikasi Pariwisata. Jakarta: Prenada Group

Deddy, Mulyana 2005. Ilmu Komunikasi. Bandung: PT Remaja Rosdakarya

http://www.kemenpar.go.id/ proceeding.conference.unpas.ac.id 